\title{
Effects of wastewater stabilization pond effluent on agricultural crops
}

\author{
${ }^{1 *}$ K. Naddafi, ${ }^{2}$ N. Jaafarzadeh, ${ }^{1}$ M. Mokhtari, ${ }^{3}$ B. Zakizadeh and ${ }^{4}$ M.R. Sakian \\ ${ }^{1}$ Department of Environmental Health Engineering, School of Public Health, Tehran University of Medical \\ Sciences, Tehran, Iran \\ ${ }^{2}$ Department of Environmental Health, Ahwaz University of Medical Science, Ahwaz, Iran \\ ${ }^{3}$ Department of Environment, Khuzestan Industrial Estate Company, Ahwaz, Iran \\ ${ }^{4}$ Water Divisions, Khuzestan Water and Power Organization, Ahwaz, Iran
}

\begin{abstract}
Wastewater reclamation and reuse is one of the best alternatives for compensating water shortages. Water supply and environmental conservation can be met through wastewater reclamation. Principally, treated wastewater is a reliable water resource, especially for periodic droughts and in arid areas. This study designed and implemented to investigate the full scale application of effluent for irrigation use. A major objective of this study is to assess on health effects and feasibility of crop irrigation by using stabilization ponds effluent of southern Hovaizeh Wastewater Treatment Plant located in Khuzestan Province. Two experimental plots of about 0.5 ha. were constructed. One of the plots irrigated by stabilization pond effluent and the other irrigated by Nisan River water. Basic parameters in two plots such as type of cultivated crops, amount of fertilizer use and lack of soil contamination have been similar in both. The only difference was the type of water applied for irrigation of agricultural crops. It was shown that high salinity of soil reduced the growth rate of agricultural crops. So, removing salinity from area should be performed before cultivation. Results gained on agricultural crops growth in two studied plots showed the growth rate and quality of crops were increased by using of stabilization pond effluent in comparison with Nissan River water.
\end{abstract}

Key words: Reuse, stabilization pond, effluent, agricultural corps, Hovaizeh WTP

*Corresponding Author, E-mail: K_naddafee@yahoo.com

\section{Introduction}

During last decade, there is a growing concern about usable water resources decrease. Currently, the world is moving towards water crisis. Water shortage is an important concern in arid areas such as Africa, Southern Asia and Middle East and even in some parts of the World which it may lead to a war crisis (Jaafarzadeh, 1996). On the other hands continued population growth, increased per capital water consumption and increased water requirements for industry and irrigation result in considerable decrease of usable water resources. Therefore, treated wastewater recycling into the hydrological cycle is of significant importance and has many benefits. The major uses of treated wastewater are in agricultural irrigation, industrial activities and groundwater recharge. The amount of water used in the above-mentioned activities depends on the properties of water catchments, meteorological and gehydrological factors and direct and indirect water consumption rate. With respect to public health, principles of engineering economy, aesthetic standards and more importantly public acceptance, wastewater reuse can be developed.
Reuse of wastewater effluent is currently receiving more attention because of water shortages. Use of treated wastewater effluent can be a new source of water (Zadhoosh, 1996). Traditionally, domestic wastewater was used as fertilizer in agriculture or as soil conditioner in some parts of Asia. However, documents on application of effluent in agriculture were found in Bazlau, Germany in 1531 and in Edinburgh in Scotland. As wastewater treatment methods developed more affection was made on treated wastewater reuse in agriculture. Especially, some specialists believe that land treatment of effluent is the best alternative (Alizadeh and Naghibi, 1996). Moreover, infiltration of effluent into soil can cause environmental degradation as well as river pollution (Kaynezhad and Ebrahimi, 1997). Two main reasons that have firstly been encouraged wastewater reuse include: 1 . River pollution can be avoided, and 2. Wastewater is an enrich source of nutrients for plants. After that water resource protection and effluent reuse in areas with water shortage have been taken into account. Scientific advances, economic consideration and more 
importantly experiments gained up to now, both encourage and discourage propel to use effluent for irrigation although these reasons are still important (Blumental and Peasey, 2000).

At the present time, most areas in Iran are suffering from water shortage and most others will experience this problem. Thus, wastewater can be a reliable source of water and after being collected it will be an available water source (Metcalf and Eddy, 2003). Investigation of potential and importance of treated wastewater reuse will help society to compare the reclaimed water and water extracted from drinking water resources in large scale.

This experiment has been done at Hovaizeh area at Khuzistan Province of Iran on 2003.

\section{Materials and Methods}

A field study was carried out to investigate the safety and feasibility of crop irrigation, which were mostly eaten raw, by treated effluent of stabilization pond received municipal wastewater. The farms chosen as study field were located adjacent to Hovaizeh wastewater treatment plant system.

Two experimental plots, each sized 0.5 ha. were chosen to study the treated effluent effects on crops through statistical analysis. One of the farms was irrigated using the stream that is divided from Nisan River. The flooded irrigation was applied on lands. In order to protect the effluent percolation in to the adjacent farm, insulation was made between the farm using nylon sheets. In addition, the farms were fenced to prevent animal's intrusion that might cause secondary pollution. In general, both farms were similar in terms of size, types of crop, amount of fertilizers used and lack of pollutants in soil; expecting that the water source used for irrigation was different to enable us to evaluate the crops and chemical (especially heavy metals) and microbial pollution that might be exist.The samples were taken from the inlet to each plot. Some examinations EC, $\mathrm{pH}$ and temperature were measure on-site and to examine the rest parameters DO, BOD, COD, TDS, alkalinity, acidity, chloride, salinity, sodium absorption ration (SAR), Nitrogen and sulfide compounds and metals including $\mathrm{Ca}, \mathrm{K}, \mathrm{Mn}, \mathrm{Na}, \mathrm{Fe}$, the samples were preserved at $4{ }^{\circ} \mathrm{C}$ and sent to the Khuzestan Central Laboratory. All the examinations were followed Standard Methods (Metcalf and Eddy, 2003). One way ANOVA was used to determine statistically significance of the characteristics of the soils irrigated by either Nissan River or treated effluent.

\section{Results}

Table 1 provides the physical and chemical parameters of the treated effluent in the inlet of two plots and those of Nisan river water; microbial quality of each source is provided in Table 2. Heavy metal contents in the crops produced in each plot are given in Table 3. Parasitic quality of the water produced from the crops of each plot is presented in Table 4 and Table 5 gives the crops development and growth, in addition to their observed characteristics. According to Table 1 it can be found that the high salinity in Nisan river as well as soil poor quality influences the permeability of the ground. Water soluble salts increase the osmotic pressure of soil water which in this turn will result in more energy consumption by plants to absorb water.

Table 1: The average physical and chemical properties of the treated effluent and Nisan river water

\begin{tabular}{|lccc|}
\hline Parameter & Unit & River & $\begin{array}{c}\text { Treated } \\
\text { Effluent }\end{array}$ \\
\hline EC & $\mu$ mohs/ cm & 3905 & 2780 \\
Temperature & ${ }^{\circ} \mathrm{C}$ & 22 & 24.2 \\
$\mathrm{pH}$ & - & 7.7 & 7.67 \\
T.S.S. & $\mathrm{mg} / \mathrm{l}$ & 599 & 607 \\
T.D.S. & $\mathrm{mg} / \mathrm{l}$ & 2188 & 1892 \\
Total & $\mathrm{mg} / \mathrm{l} \mathrm{as}$ & 584.5 & 851 \\
Hardness & $\mathrm{CaCO}$ & \\
Ca & $\mathrm{mg} / \mathrm{l}$ & 170 & 156 \\
$\mathrm{~K}$ & $\mathrm{mg} / \mathrm{l}$ & 189 & 22 \\
Mg & $\mathrm{mg} / \mathrm{l}$ & 39 & 112 \\
Na & $\mathrm{mg} / \mathrm{l}$ & 145 & 309 \\
Acidity & $\mathrm{mg} / \mathrm{l} \mathrm{as}$ & 81 & 18 \\
& $\mathrm{CaCO}$ & & \\
Alkalinity & $\mathrm{mg} / \mathrm{l} \mathrm{as}$ & 655 & 157 \\
BOD & $\mathrm{CaCO}$ & & \\
COD & $\mathrm{mg} / \mathrm{l}$ & 89 & 17 \\
Sulfate & $\mathrm{mg} / \mathrm{l}$ & 289 & 102 \\
Nitrate & $\mathrm{mg} / \mathrm{l}$ & 420 & 731 \\
Nitrite & $\mathrm{mg} / \mathrm{l}$ & 1.38 & 4.94 \\
Chloride & $\mathrm{mg} / \mathrm{l}$ & 0.066 & 0.14 \\
Salinity & $\mathrm{mg} / \mathrm{l}$ & 735 & 533 \\
SAR & - & 33.74 & 27.08 \\
\hline & - & 0.912 & 0.75 \\
\hline
\end{tabular}

Table 2: The mean total coliform and fecal coliform in Nisan river water and the treated effluent

\begin{tabular}{|lccc|}
\hline Parameter & Unit & River & $\begin{array}{c}\text { Treated } \\
\text { Effluent }\end{array}$ \\
\hline $\begin{array}{l}\text { Total } \\
\text { Coliform }\end{array}$ & $\begin{array}{c}\text { MPN/100 } \\
\text { ml }\end{array}$ & $88.7 \times 10^{5}$ & $30 \times 10^{6}$ \\
$\begin{array}{l}\text { Fecal } \\
\text { Coliform }\end{array}$ & $\begin{array}{c}\text { MPN/100 } \\
\mathrm{ml}\end{array}$ & $4.9 \times 10^{4}$ & $19 \times 10^{4}$ \\
\hline
\end{tabular}


Therefore, respiration of plant increases and the plant growth will decline as a consequence. Accordingly, it can be underfeed that no growth occurred in most farms. The relative amounts of chemicals in the ground were almost the same amount found in the irrigation water. Increased application of chemical fertilizers affects on the concentration of soil chemical properties. Thus, both kinds of irrigation waters can negatively impact the soil. Heavy metal concentrations had not any adverse effect on crops. Examinations carried out on the edible parts of the parts showed no significant difference in heavy metal contents between their concentrations in plants irrigated with Nisan River water and those irrigated with the treated effluent. The samples taken from both Nisan rivers and the treated effluent indicated high coliform contents so that chlorination process for both irrigation sources should be improved to reduce the risks related to crops contamination by pathogens. Crop growth rate were significantly different according to the irrigation source and ground chemical quality.

The study showed that of overall 36 garden personal farms irrigated by Nisan river water, crop production growth in 7 farms $(19.4 \%)$ was $20-60 \%$, in 10 farms (27.7\%) was 5-30\% , and in 19 farms $(25.7 \%) n$ growth was recorded, while of overall 28 farms irrigated by the treated effluent, growth in 6 farms $(21.4 \%)$ was $10-100 \%$, in 4 farms $(14.2 \%)$ was $20-60 \%$, in 4 farms $(14.2 \%)$ was $5-30 \%$, and in 14 farms (50\%) no growth was observed.

Of overall 44 sweet basil farms irrigated by Nisan river water, growth in 21 farms $(47.7 \%)$ was 30 $60 \%$, in 10 farms $(22.7 \%)$ was $5-30 \%$ and in 13 farms (29.5\%) no growth was observed, while the 24 farms irrigated by the treated effluent showed no growth and they were completely dry. Of overall
32 radishes farm irrigated by Nisan River water, growth in 10 farms $(31.2 \%)$ was $30-60 \%$, in 9 farms $(28.1 \%)$ was $5-30 \%$ and in 13 farms (40.6\%) no growth was occurred, while the 20 radish farms irrigated by the treated effluent showed no growth in plants.

In several rows of cucumber irrigated by Nisan river water no growth was observed, while of overall 15 cucumber farms irrigated by the treated effluent, growth in 5 farms (33.3\%) was 30-50\% , in 6 farms (40\%) was $15-30 \%$ and in 4 farms (33.3\%) was 5$15 \%$.

\section{Discussion and Conclusion}

Gradually the uncommon water resources such as treated effluents has found an assured place in human consumption cycle, because with urban development and increased public health a lot effort has been put into supply water. Thus, a potential source of water in urban areas can be treated effluents that have continuously been increased.

From the above-mentioned results and the analyses carried out on the water and rivereffluent it can be concluded that low crop production may result from ground poor quality (high salinity). The existing high salinity of the studied area should have been improved before growing crops. With comparison of the results obtained from crops production in both plots, it is revealed that growth was quantitatively and qualitatively higher in the farms irrigated by the treated effluent than that of the farms irrigated by Nisan river water. Numerous works on this subject earlier. For instance, Alizadeh, et al., (1996) showed that vegetables (tomato, lettuce, cucumber and carrot) irrigation by treated effluent increased their development in comparison with irrigation by water.

Table 3: The mean concentraition of heavy metal in Nisan river water and the treated effluent

\begin{tabular}{|c|c|c|c|c|c|c|c|c|c|}
\hline \multirow{2}{*}{ Metal } & \multirow{2}{*}{ Unit } & \multicolumn{2}{|c|}{ Garden Purslane } & \multicolumn{2}{|r|}{ Sweet Basil } & \multicolumn{2}{|r|}{ Radish } & \multicolumn{2}{|c|}{ Cucumber } \\
\hline & & River & Treated Effluent & River & Treated Effluent & River & Treated Effluent & River & $\begin{array}{l}\text { Treated } \\
\text { Effluent }\end{array}$ \\
\hline $\mathrm{Ni}$ & $\mathrm{mg} / \mathrm{l}$ & 85 & 270 & 50 & - & 45 & 250 & 90 & 85 \\
\hline $\mathrm{Hg}$ & $\mathrm{mg} / \mathrm{l}$ & 0.3 & 0.04 & 0.06 & - & - & 0.95 & 0.12 & 0.38 \\
\hline Cd & $\mathrm{mg} / \mathrm{l}$ & 30 & 30 & 30 & - & 40 & 50 & 20 & 30 \\
\hline $\mathrm{Cr}$ & $\mathrm{mg} / \mathrm{l}$ & 85 & 50 & 20 & - & 40 & 820 & 30 & 50 \\
\hline
\end{tabular}


Table 4: Parasitic quality of the water generated from crops washing by River water and the treated effluent

\begin{tabular}{|c|c|c|c|c|}
\hline \multirow{2}{*}{ Crop } & \multicolumn{2}{|c|}{$\begin{array}{c}\text { Irrigation by River } \\
\text { Water }\end{array}$} & \multicolumn{2}{|c|}{$\begin{array}{c}\text { Irrigation by } \\
\text { Treated Effluent }\end{array}$} \\
\hline & $\begin{array}{c}\text { Sample } \\
1\end{array}$ & $\begin{array}{c}\text { Sample } \\
2\end{array}$ & $\begin{array}{c}\text { Sample } \\
1\end{array}$ & $\begin{array}{c}\text { Sample } \\
2\end{array}$ \\
\hline $\begin{array}{l}\text { Garden } \\
\text { Purslane }\end{array}$ & - & - & - & - \\
\hline $\begin{array}{l}\text { Sweet } \\
\text { Basil }\end{array}$ & - & - & - & Nematode \\
\hline Radish & & $\begin{array}{l}\text { Live } \\
\text { larvae }\end{array}$ & - & $\begin{array}{l}\text { Live } \\
\text { larvae }\end{array}$ \\
\hline Cucumber & - & - & - & \\
\hline
\end{tabular}

Table 5: The crops growth irrigated by Nisan water and the treated effluent

\begin{tabular}{|c|c|c|}
\hline Crop & River & Treated Effluent \\
\hline $\begin{array}{l}\text { Garden } \\
\text { Purslane }\end{array}$ & $\begin{array}{l}\text { Growth in } 7 \\
\text { Farms: } 30-60 \% \\
\text { Growth in } 10 \\
\text { Farms: 5-20\% } \\
\text { Growth in } 19 \\
\text { Farms: no } \\
\text { growth } \\
\text { Overall Farms: } \\
36\end{array}$ & $\begin{array}{l}\text { Growth in } 6 \\
\text { Farms: } 70- \\
100 \% \\
\text { Growth in } 4 \\
\text { Farms: } 30-60 \% \\
\text { Growth in } 4 \\
\text { Farms: } 30-50 \% \\
\text { Growth in } 14 \\
\text { Farms: no } \\
\text { growth } \\
\text { Overall farms: } \\
28\end{array}$ \\
\hline $\begin{array}{l}\text { Sweet } \\
\text { Basil }\end{array}$ & $\begin{array}{l}\text { Growth } 21 \\
\text { Farms: } 30-60 \% \\
\text { Growth in } 10 \\
\text { Farms: } 30-50 \% \\
\text { Growth in } 12 \\
\text { Farms: no } \\
\text { growth } \\
\text { Overall Farms: } \\
34\end{array}$ & $\begin{array}{l}\text { No growth in } \\
\text { any Farms } \\
\text { Overall Farms: } \\
34\end{array}$ \\
\hline Radish & $\begin{array}{l}\text { Growth in } 10 \\
\text { Farms: } 30-60 \% \\
\text { Growth in } 12 \\
\text { Farms: } 5-30 \% \\
\text { Growth in } 13 \\
\text { Farms: no } \\
\text { growth } \\
\text { Overall Farms: } \\
32\end{array}$ & $\begin{array}{l}\text { No growth in } \\
\text { any Farms } \\
\text { Overall Farms: } \\
20\end{array}$ \\
\hline Cucumber & $\begin{array}{l}\text { No growth in } \\
\text { any farm }\end{array}$ & $\begin{array}{l}\text { Growth in } 5 \\
\text { rows: } 30-50 \% \\
\text { Growth in } 6 \\
\text { rows: } 15-30 \% \\
\text { Growth in } 4 \\
\text { rows: } 5-15 \% \\
\text { Overall rows: } \\
15\end{array}$ \\
\hline
\end{tabular}

They stated that as treated effluent is a rich source of nutrients needed by plants, it would increase plant growth 60 that using treated effluent for irrigation of the studied plants can be equal to 25 tone application of manure on land (Zadhoosh, 1996). Zadhoosh (1996) stated that using raw wastewater for wheat farm irrigation increased grain and wheat weight in comparison with irrigation increased grain and wheat weight in comparison with irrigation by water (Abedi and Najafi, 2001). Apparently, wastewater reuse has some disadvantages. For instance, wastewater disposal into seasonal Shiraz river to be reused can result in adjacent soil pollution and transmission of some heavy metals to plants in long term (AWWA, 1998). In general, care should be exercised for irrigation of raw edible vegetables by wastewater effluent. People may be reluctant to use the vegetables irrigated by wastewater effluent, although they do not have any health effect. Accordingly, most consultant engineers do not recommend using wastewater effluent for plants irrigation such as vegetables. However, there is no scientific evidence to encourage or discourage wastewater effluent for irrigation use.

\section{References}

Abedi, M. J. and F. Najafi, Application of treated domestic effluent in agriculture. Publication of Iranian national irrigation and drainage committee.

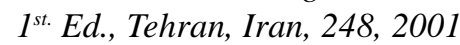

Alizadeh, A. and A. Naghibi, Use of treated domestic wastewater in irrigation. Proceeding of the second national water and soil issues congress, Tehran, Iran, 369, 1996

AWWA, WEF and APHA, Standard methods for the examination of water and wastewater, $14^{\text {th. }}$ Ed., 1998

Blumental, U. and A. Peasey, Guidelines for wastewater reuse in agriculture and aquaculture. Ult Ed. Loughborough University, 2000

Jaafarzadeh, N., Effect of wastewater of Shiraz city for crops irrigation on heavy metal increase in soil and plants. Proceedings of the second national water and soil congress, Published by agricultural education and development organization, Tehran, Iran, 369, 1996

Kaynezhad, M. A. and S. Ebrahimi, Environmental engineering. Sahand university publication, $1^{\text {st. Ed., }}$ Tabriz, Iran, 545, 1997 
Metcalf and Eddy, Wastewater engineering: Treatment

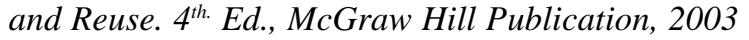

Rowe, D. and I. Abdelmagid, Handbook of wastewater reclamation and reuse. $2^{\text {nd. }}$ Ed., Lews publisher, CRC Press, 420, 1995
Zadhoosh., Wastewater effluent irrigation effects on soil and plants M.S. thesis, Tehran university, Tehran, Iran, 1996 